УДК 347.2

\title{
ФОРМЫ И СПОСОБЫ ЗАЩИТЫ ИМУЩЕСТВЕННЫХ ПРАВ СУПРУГОВ
}

\begin{abstract}
Сербин Михаил Викторович
Заведующий кафедрой государственного права, кандидат юридических наук, доцент, Вице-президент Молодежного союза юристов Российской Федерации

Сербина Лейла Арифовна

Старший преподаватель кафедры гражданского права ФГАОУ ВО «Санкт-Петербургский государственный университет аэрокосмического приборостроения»
\end{abstract}

\begin{abstract}
Аннотация: В представленной статье исследуется вопрос о формах и способах защиты имущественных прав супругов. Делается вывод о том, что супруги обладают широким спектром возможностей по защите нарушенных прав.

Ключевые слова: формы, способы, супруги, защита, имущественные права.

\section{FORMS AND METHODS OF PROTECTION OF PROPERTY RIGHTS OF SPOUSES}

\section{Serbin Mikhail Viktorovich \\ Serbina Leila Arifovna}

\begin{abstract}
The presented scientific article examines the question of ways to protect the property rights of spouses. It is concluded that spouses have a wide range of opportunities to protect violated rights.
\end{abstract}

Key words: forms, methods, spouses, protection, property rights.

Приступая к рассмотрению форм и способов имущественной защиты прав супругов, необходимо напомнить, что имущественными правами супругов называют права по поводу имущества, имеющие имущественно-стоимостной характер, возникающие после регистрации брака и урегулированные нормами 


\section{ЭКОНОМИКА, УПРАВЛЕНИЕ, ПРАВО: АКТУАЛЬНЫЕ ВОПРОСЫ И ВЕКТОРЫ РАЗВИТИЯ}

семейного права [8, с.100], основанные на юридическом равенстве сторон. Более того, имущественные права также возникают посредством заключения брачных договоров и иных соглашений.

Главный способ защиты имущественных прав супругов представляет собой признание права. Данный способ применяют в случае признания, оспаривания или отрицания наличия у лица соответствующего права. Так, указанный способ применяется в рамках признания права совместной собственности на личное имущество каждого из супругов (ст. 37 СК РФ). Здесь же можно говорить о таком способе защиты как право требования компенсации соразмерно причитающейся доли в общем имуществе супругов, предусмотренной в соответствии с гл. 60 ГК РФ.

Следующим способом защиты можно назвать восстановление положения, существовавшего до нарушения права. Указанный способ носит универсальный характер, то есть он может быть применен для защиты любого субъективного права. Целью данного способа является восстановление положения супруга, чьи права были нарушены, путем устранения последствий правонарушения [12, c.11].

Переходя к рассмотрению способов защиты имущественных прав по поводу взаимного материального содержания, необходимо отметить, что в качестве источника возникновения таких прав выступают положения, закрепленные гл. 14 СК РФ, а также особый вид семейно-правового договора соглашение об уплате алиментов.

В случае нарушения права, основой которого является соглашение об уплате алиментов, законодателем в ст. 101, 102 СК РФ предусмотрен уже рассмотренный нами ранее такой способ защиты, как признание сделки недействительной. Помимо указанного способа к данной категории прав могут также применяться такие гражданско-правовые способы защиты, как признание права, возмещение убытков, взыскание неустойки, присуждение к исполнению обязанности в натуре, а также компенсация морального вреда.

Возмещение убытков и взыскание неустойки как способы защиты имущественных прав также носят универсальный характер, и соответственно могут применяться в семейном праве [6, с.145]. Применение данных мер защиты в ряде конкретных случаев напрямую закреплено в СК РФ (п. 2 ст. 115). В соответствии с п. 1 ст. 393 ГК РФ, обращение к данным способам защиты возникает в случае неисполнения или ненадлежащего исполнения обязательств, вытекающих из заключенного договора. 


\section{ЭКОНОМИКА, УПРАВЛЕНИЕ, ПРАВО: АКТУАЛЬНЫЕ ВОПРОСЫ И ВЕКТОРЫ РАЗВИТИЯ}

Следующий способ защиты - присуждение к исполнению обязанности в натуре относится к числу способов, осуществляемых управомоченным лицом в процессе судебной защиты нарушенного права [11, с.8]. В рамках семейного права данный способ применяется при невыполнении обязанности по содержанию.

Применение компенсации морального вреда в качестве способа защиты имущественных прав прямо оговорено только в п. 4 ст. 30 СК РФ, согласно которому добросовестный супруг может требовать возмещения причиненного морального вреда в соответствии с положениями, закрепленными ГК РФ. В целом обращение к данному способу не противоречит семейному законодательству, однако, отсутствие прямого указания на возможность использования такого способа защиты в других случаях, делает его малоприменимым на практике [4, с.844].

Необходимо сказать, что в соответствии со способами защиты имущественных прав супругов, которые возникают в отношении их совместных долгов, в СК РФ закреплено правило о пропорциональном распределении общих долгов супругов между каждым из них согласно присужденным долям в общем имуществе супругов (п. 3 ст. 39). Вместе с этим, как указывает М.А. Астахова, здесь можно говорить о возникновении у супругов такого права, как «право на выделение части общего долга соразмерной доле присужденного имущества» [3, с.32]. В целях защиты данного права зачастую применяют гражданско-правовые способы защиты, которые выражаются, как правило, в признании самого права, а также в восстановление нарушенного права.

Следующим способом защиты данной категории имущественных прав можно назвать предъявление регрессного требования [2, с.22]. То есть супруг, исполнивший обязательство, возникшее в интересах семьи, в соответствии со ст. 325 ГК РФ имеет право требовать взыскания с другого супруга денежных средств. Использование данного способа обусловлено сложностью получения согласия кредитора на перевод супругом, выступающим должником по обязательству, своего долга на другого супруга, в случае раздела общего долга. В этом же случае вместо предъявления регрессного требования, истцом может быть выбран способ защиты в виде требования об отступлении от общего правила равенства долей супругов в общем имуществе.

Среди способов защиты имущественных прав по поводу совместного долга также выделяют такой, как признание обязательства солидарным. Таким 
образом, в соответствии с п.2 ст.45 СК РФ применение данного способа возможно, если супругом, являющимся стороной в обязательстве, будет доказано, что обязательство возникло в интересах семьи, а также, что все полученное по обязательству было направлено на нужды семьи.

Помимо рассмотренных юрисдикционных способов защиты имущественных прав, существует также неюрисдикционная форма защиты, которая осуществляется непосредственно сторонами материального правоотношения и только в рамках этого правоотношения. Несмотря на то, что в СК РФ прямо не оговорена такая форма защиты, некоторые ученые, например, Л.М. Пчелинцева [9, с.78], Е.В. Каймакова [7, с.9] признают ее допустимой и правомерной. Подтверждая данную точку зрения, необходимо обратиться к Конституции Российской Федерации, в п. 2 ст. 45 которой прямо оговорено право защиты своих прав и свобод любыми способами, не противоречащими закону.

Способами самозащиты, применяемыми исключительно в семейном праве можно назвать отказ супруга в выдаче согласия другому супругу на распоряжение совместно нажитым имуществом, а также заключение семейноправовых договоров. Целью первого способа является установление контроля со стороны супруга, не являющегося титульным собственником, за соблюдением своих прав при совершении вторым супругом действий, направленных на распоряжение их общим имуществом [13, с.21]. В основе второго способа лежит непосредственное заключение супругами (бывшими супругами) брачного договора или соглашения о разделе имущества, а также соглашения об уплате алиментов супругу. Так, посредством заключения договора или иного соглашения, касающегося имущественных отношений супруги вправе менять режим общей собственности в отношении рассматриваемого имущества во избежание претензий на него со стороны третьих лиц (например, в случае взыскания кредитора задолженности с супруга-должника) [5, с.238].

Обязательственно-правовые способы защиты, как и вещно-правовые способы имеют своей целью достижение определенного результата, а именно, защита отдельных субъективных прав, а в ряде случаев- получение денежной суммы $[10$, с.53].

Таким образом, на основании проведенного анализа можно сделать следующие выводы: 


\section{ЭКОНОМИКА, УПРАВЛЕНИЕ, ПРАВО: АКТУАЛЬНЫЕ ВОПРОСЫ

- имущественные права супругов можно условно разделить на три категории прав, а именно возникающие по поводу общей собственности супругов, возникающие по поводу взаимного материального содержания супругов, а также права, возникающие по поводу совместных долгов;

- защита имущественных прав обеспечивается применением предусмотренных законом способов защиты;

- для защиты имущественных прав супругов можно использовать не только семейно-правовые способы защиты, но и гражданско-правовые, в связи с тем, что регулирование имущественных прав супругов находится не только в плоскости семейного законодательства, но и гражданского;

- среди семейно-правовых способов защиты выделяют такие способы защиты, как получение согласия супруга на проведение другим супругом сделки по распоряжению общим имуществом; отступление от общего правила равенства долей супругов в совместном имуществе; правило о пропорциональном распределении общих долгов супругов в соответствии с присужденными долями при разделе общего имущества;

- к гражданско-правовым способам защиты имущественных прав супругов относят следующие: признание сделки недействительной и применение последствий недействительности для сделок; прекращение или изменение правоотношения; признание права; право требования компенсации соразмерно причитающейся доли в общем имуществе супругов; восстановление положения, существовавшего до нарушения права; возмещение убытков; взыскание неустойки; присуждение к исполнению обязанности в натуре; компенсация морального вреда, а также предъявление регрессного требования и признание обязательства солидарным;

- при защите имущественных прав супругов допустимо применение самозащиты;

- супруги (бывшие супруги) обладают широким спектром возможностей для защиты своих имущественных прав.

\section{Список литературы}

1. Андреева Е.В. Меры защиты и ответственности при реализации имущественных прав и охраняемых законом интересов супругов // Вестник КГТУ. Государство и право: вопросы теории и практики (Серия «Юридические науки»). - 2015. №5. - С. 74. 


\section{ЭКОНОМИКА, УПРАВЛЕНИЕ, ПРАВО: АКТУАЛЬНЫЕ ВОПРОСЫ И ВЕКТОРЫ РАЗВИТИЯ}

2. Антонов А.Г. Способы защиты имущественных прав супругов при разделе общего имущества // Вектор науки ТГУ. Серия: Юридические науки. 2016. № 4(27). - С. 22.

3. Астахова М.А. Способы защиты семейных прав: вопросы теории и практики: монография. - Саарбрюккен: LAP LAMBERT, 2018. - C.32

4. Геворгян М.А. К вопросу о способах защиты семейных прав в свете изменений семейного кодекса российской федерации // Право и политика. 2016. № 7(199). - С. 844.

5. Григоров А.А. Способы самозащиты в семейном праве // Вестник КГУ им. Н.А. Некрасова. - 2016. №3. - С. 238.

6. Гурулева Э.А., Иванова Н.А. Отдельные проблемы возмещения убытков и взыскания неустойки как мера гражданско-правовой ответственности за нарушение обязательств // Гуманитарные, социальноэкономические и общественные науки. - 2019. № 10. - С. 145

7. Каймакова Е.В. Защита семейных прав: автореф. дис. ... канд. юрид. Наук: 12.00.03 / Каймакова Елена Васильевна. - Курск, 2011. - С.9

8. Курбанов Р.А. Семейное право: учебник / Курбанов Р.А., Богданов Е.В., Гуреев В.А. [и др.] под ред. Р. А. Курбанова. - Москва : Проспект, 2015. C. 100

9. Пчелинцева Л.М. Семейное право: учебник. -М: Норма. 2016. - С.78

10. Сербин М.В. Отдельные виды обязательственно-правовых способов защиты имущественных прав граждан // В сборнике: ПРАВОВАЯ СИСТЕМА И COВРЕМЕННОЕ ГОСУДАРСТВО: ПРОБЛЕМЫ, ТЕНДЕНЦИИ И ПЕРСПЕКТИВЫ РАЗВИТИЯ. сборник статей VII Международной научнопрактической конференции. Пенза, 2020. С. 52-54.

11. Стряпунина Е.А. Способы и формы защиты гражданских прав, их виды // Альманах мировой науки. - 2015. №1-4(1). - С. 8.

12. Тутынина В.В. Восстановление положения, существовавшего до нарушения права, как способ защиты гражданских прав: автореф. дис.... канд. юрид. наук: 12.00.03 / Тутынина Виктория Викторовна- Москва, 2016. - С.11

13. Чашкова С.Ю. Институт согласия на совершение сделки в свете изменений гражданского законодательства: Учебное пособие / С.Ю. Чашкова. М.: РПА Минюста России, - 2014. - С.21

(C) М.В. Сербин, Л.А. Сербина, 2021. 